\title{
Sub-Saharan African migrants living with HIV acquired after migration, France, ANRS PARCOURS study, 2012 to 2013
}

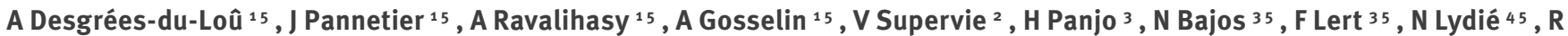 \\ Dray-Spira 25 , The Parcours Study Group 5 \\ 1. CEPED, UMR Institut de Recherche pour le développement (IRD)-Université Paris Descartes, Sorbonne Paris Cité, Paris, France \\ 2. Sorbonne Universités, UPMC Univ Paris 06, Institut National de la Santé et de la Recherche Médicale (INSERM), Institut Pierre \\ Louis d’Epidémiologie et de Santé Publique (IPLESP UMRS 1136), F75013, Paris, France \\ 3. Institut National de la Santé et de la Recherche Médicale (INSERM), CESP-U 1018, Villejuif, France \\ 4. Institut national de prévention et d'éducation pour la santé (INPES), Saint-Denis, France \\ 5. www.parcours-sante-migration.com
}

Correspondence: Annabel Desgrées-du-Loû (annabel.desgrees@ird.fr)

We estimated the proportion of migrants from subSaharan Africa who acquired human immunodeficiency virus (HIV) while living in France. Life-event and clinical information was collected in $\mathbf{2 0 1 2}$ and 2013 from a random sample of HIV-infected outpatients born in sub-Saharan Africa and living in the Paris region. We assumed HIV infection in France if at least one of the following was fulfilled: (i) HIV diagnosis at least 11 years after arrival in France, (ii) at least one negative HIV test in France, (iii) sexual debut after arrival in France. Otherwise, time of HIV infection was based on statistical modelling of first $\mathrm{CD}_{4}^{+} \mathrm{T}$-cell count; infection in France was assumed if more than $50 \%$ (median scenario) ormore than $95 \%$ (conservative scenario) of modelled infection times occurred after migration. We estimated that $49 \%$ of 898 HIV-infected adults born in sub-Saharan Africa (95\% confidence interval (CI): 45-53) in the median and $35 \%$ (95\% Cl: 31-39) in the conservative scenario acquired HIV while living in France. This proportion was higher in men than women (44\% (95\% Cl: $37-51)$ vs $30 \%$ (95\% Cl: $25-35)$; conservative scenario) and increased with length of stay in France. These high proportions highlight the need for improved HIV policies targeting migrants.

\section{Introduction}

In France, as in most countries in Western Europe, migrants from sub-Saharan Africa are disproportionally affected by the human immunodeficiency virus (HIV) epidemic [1,2]. In 2012, people born in sub-Saharan Africa accounted for $31 \%$ of new HIV diagnoses [3] and for $24 \%$ of the whole population of persons living with HIV (PLWHIV) in France [4], although they represented only ca $1 \%$ of the French general population [5].
Among people from sub-Saharan Africa, the number of new diagnoses has decreased in France since 2003, although incidence remains 29 times higher in men and 69 times higher in women compared with Frenchnational heterosexuals [6].

Most people do not know where and when they acquired HIV. Among migrants, HIV acquisition has long been considered to predominantly occur before migration because of generalised HIV epidemics in sub-Saharan African countries [7]. However, evidence from various European countries in the past decade suggests that a substantial proportion of migrants from sub-Saharan Africa acquired HIV while they were living in Europe [8]. In the United Kingdom (UK), this proportion was recently estimated at $31 \%$ using a modelling approach based on $\mathrm{CD}_{4}{ }^{+}$T-cell counts [9].

Such an estimate is not currently available for most European countries, although it is crucial to guide public health monitoring and allocation of resources for prevention. Indeed, if HIV is acquired after migration, resources should be allocated not only to improve timely HIV diagnosis but also to prevent the spread of HIV among migrants.

In this study, in order to guide HIV policies for migrants in France, we estimated the proportion of sub-Saharan migrants who acquired HIV infection after their arrival in France. This estimation was performed using lifeevent data and clinical data collected in the PARCOURS study, a large life-event survey [10] of people from subSaharan Africa living in the metropolitan area of Paris, the French area most affected by HIV [3] and with the 
largest population of migrants from sub-Saharan Africa [5].

\section{Methods}

\section{Study design}

The PARCOURS study is a cross-sectional retrospective life-event history survey conducted between February 2012 and May 2013 among a random sample of subSaharan migrants receiving care for HIV at hospitals in the Paris metropolitan area. Of the 41 hospital services following HIV-infected patients in the Paris region, we selected the 37 services where at least 100 patients from sub-Saharan Africa were followed up. Within this sampling frame, hospital services were selected by stratified randomisation, the sampling probability of each HIV service being proportional to the size of the service's HIV caseload. A total of 27 services were chosen and 24 agreed to participate in the study. The caseload of these 24 services represented $72 \%$ of all sub-Saharan migrants followed for HIV in the Paris metropolitan area.

In each participating department, all outpatients born in a sub-Saharan African country, aged 18 to 59 years and diagnosed HIV-positive at least three months ago, were eligible. Physicians invited all eligible patients, except those with major cognitive or health impairments, to participate and collected their written consent. Professional interpreters were available on demand. Of a total of 1,829 eligible outpatients, 141 were excluded, and the participation rate among the remaining patients was $55 \%$, resulting in a total of 926 participants. Among the participants, detailed information on migration history, socioeconomic conditions, sexual activity and health over the lifetime was collected anonymously through a standardised life-event questionnaire administered face-to-face by a trained professional interviewer independent from the clinic staff. The interview occurred in the clinic setting in a private room to ensure confidentiality. Each dimension of interest was documented for each year from birth until the time of data collection. Clinical and laboratory information were documented from medical records available in the health service where the survey was done. Basic data about non-participants were collected anonymously. There were no major differences between participants and non-participants in the demographic or clinical characteristics: the participation rate was higher among unemployed men compared with those working $(60.1 \%$ vs $49.0 \%, p=0.05)$, but did not vary by sex, age, or $\mathrm{CD}_{4}^{+} \mathrm{T}$-cell level. Participants received a voucher over EUR 15. The study was approved by the French National Commission for Data Protection and Liberties (CNIL, decision DR-2011-484). The complete survey protocol is registered on Clinicaltrials.gov (NCTo2566148).

\section{Information of interest}

Information on year of HIV diagnosis was documented both from the participants' reports and medical records. Both sources provided concordant information (i.e. same year $+/-1)$ in $81 \%(731 / 898)$ of the cases. In case of discordance, we retained the earliest date. Patient-reported years of arrival in France, negative HIV tests (if ever) and year of first intercourse were available in the life-event questionnaire. $\mathrm{CD}_{4}{ }^{+} \mathrm{T}$-cell counts at the time of (i) HIV diagnosis, (ii) initiation of antiretroviral therapy (ART) and (iii) interview were extracted from medical records. We defined the first measurement of $\mathrm{CD}_{4}{ }^{+} \mathrm{T}$-cell count as $\mathrm{CD}_{4}{ }^{+} \mathrm{T}$-cell count at HIV diagnosis or, in case of missing information at diagnosis $(n=30)$, as first $\mathrm{CD}_{4}{ }^{+} \mathrm{T}$-cell count available before initiation of ART.

\section{Estimation of HIV acquisition after arrival in France}

To assess whether HIV acquisition occurred before or after arrival in France, we used a combined method mixing life-event and $\mathrm{CD}_{4}{ }^{+} \mathrm{T}$-cell data.

Based on life-event data, we considered that HIV infection had been acquired before arrival in France if HIV diagnosis occurred before living in France. In addition, we assumed that HIV infection had probably been acquired after arrival in France if at least one of the following life-event criteria were fulfilled: (i) HIV diagnosis at least 11 years after arrival in France $[11,12]$, (ii) at least one negative HIV test in France, (iii) first sex after arrival in France. If none of these criteria was fulfilled, we estimated the duration from HIV infection to measurement of first $\mathrm{CD}_{4}{ }^{+} \mathrm{T}$-cell count using statistical modelling of the decline in $\mathrm{CD}_{4}^{+} \mathrm{T}$-cell count based on a method previously described [13].

As we did not have information related to the seroconversion for PARCOURS respondents, we modelled the decline in $\mathrm{CD}_{4}{ }^{+} \mathrm{T}$-cell using a cohort of West African seroconverters: the ANRS 1220 PRIMO-Cl cohort of HIV-1 seroconverters in Abidjan, Côte d'Ivoire [13,14]. The PRIMO-Cl cohort consisted of 351 blood donors (61\% men; median age at HIV infection: 28.8 years; interquartile range (IQR): 25-34) followed from 1997 to 2011, with documented negative and first positive HIV antibody test dates and at least two $\mathrm{CD}_{4}{ }^{+} \mathrm{T}$-cell counts available before commencement of ART or death. The decline in $\mathrm{CD}_{4}{ }^{+} \mathrm{T}$-cell count (square root-transformed) over time was estimated using a linear mixed model with random intercept and slope, adjusted for individual $\mathrm{CD}_{4}{ }^{+} \mathrm{T}$-cell count at first $\mathrm{CD}_{4}{ }^{+} \mathrm{T}$-cell count measure $\left(x_{1}\right)$ duration from estimated date of HIV seroconversion to first $\mathrm{CD}_{4}{ }^{+}$T-cell count measure $\left(x_{2}\right)$ and age at HIV seroconversion $\left(x_{3}\right){ }^{*}$ With the fixed effects obtained from the fitted linear mixed model in this population of seroconverters, we first derived a formula to estimate the duration $\Delta t$ from HIV seroconversion to any given $\mathrm{CD}_{4}{ }^{+} \mathrm{T}$-cell count $\left(\mathrm{CD}_{4}\right)$ :

$$
\Delta t=\frac{\left(\sqrt{C D 4_{t}}-\left(12.108+0.02 x_{1}+0.974 x_{2}-0.002 x_{3}\right)\right)}{-0.675-0.001 x_{1}}
$$


This formula was then used to estimate the duration from HIV seroconversion to first $\mathrm{CD}_{4}{ }^{+} \mathrm{T}$-cell measurement before ART initiation for PARCOURS respondents.

For PARCOURS respondents, we simulated $x_{1}, x_{2}$ and $x$ using the observed multivariate distribution in the PRIMO-Cl seroconverters cohort. For each PARCOURS respondent, we simulated 500 values of $x_{1}, x_{2}$ and $x_{3}$ from a multivariate normal distribution [15] in order to yield 500 extrapolated durations from seroconversion to first measurement of $\mathrm{CD}_{4}{ }^{+} \mathrm{T}$-cell count. Then, we added three months to these durations to account for the duration between HIV infection and seroconversion.

The proportion of individuals having acquired HIV infection while living in France was estimated according to two scenarios. In the median scenario, the infection in each individual was assumed to have occurred after arrival in France if more than $50 \%$ of the simulated durations fell within the period of their stay in France, while the conservative scenario required $95 \%$ of durations within the period of staying in France.

Associations between HIV acquisition while living in France according to the conservative scenario and age at arrival in France, time lived in France before HIV diagnosis, region of birth in sub-Saharan Africa and time point of HIV diagnosis were analysed with bivariate and multivariate logistic regression models, for men and women separately. Multivariate models were adjusted for all variables mentioned above.

Data were weighted according to each individual's probability of inclusion in the survey, and the weights applied to all percentages. Analyses were conducted using STATA 13.0 (Stata Corp., College Station, Texas, United States).

\section{Results}

Life-event or $\mathrm{CD}_{4}{ }^{+} \mathrm{T}$-cell data were missing for 28 individuals who were excluded from the analysis. Among the 898 respondents included, 550 were women and 348 were men. Median age at arrival in France was 28 years for women (IQR: 23-34) and 30 years for men (IQR: 25-37). Main countries of origin were Côte d'Ivoire (24\%), Cameroon (20\%), Democratic Republic of the Congo (13\%), Mali ( $9 \%$ ) and Congo (Brazzaville) ( $7 \%)$. The majority $(81 \%)$ had at least a secondary educational level. At the time of interview, respondents had a median age of 43 years (IQR: 36-49; women: 40 years (IQR: 35-46); men: 47 years (IQR: 39-52)) and their median length of stay in France was 12 years (IQR: 7-20). At the time of HIV diagnosis, median time spent in France was three years (IQR: 1-9) and median $\mathrm{CD}_{4}^{+}$ T-cell count was $274 / \mathrm{mm}^{3}$ (IQR: $\left.129-430\right)$.

As shown in the Figure, of the 898 respondents included in the final study sample, 133 had been diagnosed with HIV before arrival in France and 765 had been diagnosed in France between 1983 and 2012. Overall 228 respondents were ascertained to have acquired HIV while living in France based on life-event criteria: 137 had been diagnosed at least 11 years after arrival in France, 63 had a history of negative HIV test in France, and 28 had their first sexual intercourse in France and had been infected neither perinatally nor through blood transfusion. Among the 537 who did not fulfil these criteria, based on first available $\mathrm{CD}_{4}{ }^{+}$ T-cell count, 197 were ascertained by modelling to have acquired HIV after arrival in France according to the median scenario and 69 according to the conservative scenario (Figure). Overall, this led to estimates of $49 \%$ (95\% Cl: $45-53)$ and $35 \%(95 \% \mathrm{Cl}: 31-39)$ of sub-Saharan African migrants having acquired HIV while living in France, applying, respectively, the median and the conservative scenario.

This proportion who had acquired HIV after arrival in France was higher in men than in women $(44 \%$ (95\% $\mathrm{Cl}: 37-51)$ vs $30 \%(95 \% \mathrm{Cl}: 25-35)$ in the conservative scenario) and among those who arrived in their youth ( 25 years-old). It increased with the length of stay in France after migration. After adjustment for other variables, the proportion increased in the groups diagnosed most recently (odds ratio (OR) for 2008-12 vs $1996-2002=2.76(95 \% \mathrm{Cl}: 0.74-10.29)$ for men and 2.50 (95\% Cl: $1.00-6.24)$ for women). No difference was found according to educational level and region of birth (Table).

\section{Discussion}

To our knowledge, this study is the first to provide an estimate of the proportion of sub-Saharan migrants having acquired HIV after arrival in France.

Our estimation was based on data from a random sample of HIV-positive hospital outpatients in the greater Paris metropolitan area. Since this region concentrates the major part of PLWHIV born in sub-Saharan Africa living in France (69\% of women and $74 \%$ of men) [16] and HIV care in France is essentially provided at hospital [17], our results are likely to apply to the majority of sub-Saharan migrants followed for HIV in France.

Our results suggest that as much as one third to half of sub-Saharan African migrants followed for HIV care in France may have acquired HIV while living in France. French national HIV case surveillance data previously showed that $28 \%$ of sub-Saharan migrants newly HIVdiagnosed in France in 2003 to 2010 were infected with a B subtype, which is very rare in Africa, and are thus likely to have acquired HIV in Europe [18]. By comparison, when restricting our study to individuals diagnosed during the same period (since 2003, $\mathrm{n}=508)$, we obtained an estimation of $35 \%(95 \% \mathrm{Cl}$ : 29-40) in the conservative scenario. This higher estimation is consistent with the fact that some migrants may have acquired a non-B HIV subtype in France, in particular within intra-African sexual networks. We found that men were more likely than women to have acquired HIV after migration. Such a result is consistent with the epidemiological pattern of the HIV 


\section{FIGURE}

Assignment of HIV acquisition among Sub-Saharan African migrants living with HIV in the Paris metropolitan area, February 2012-May $2013(\mathrm{n}=898)$

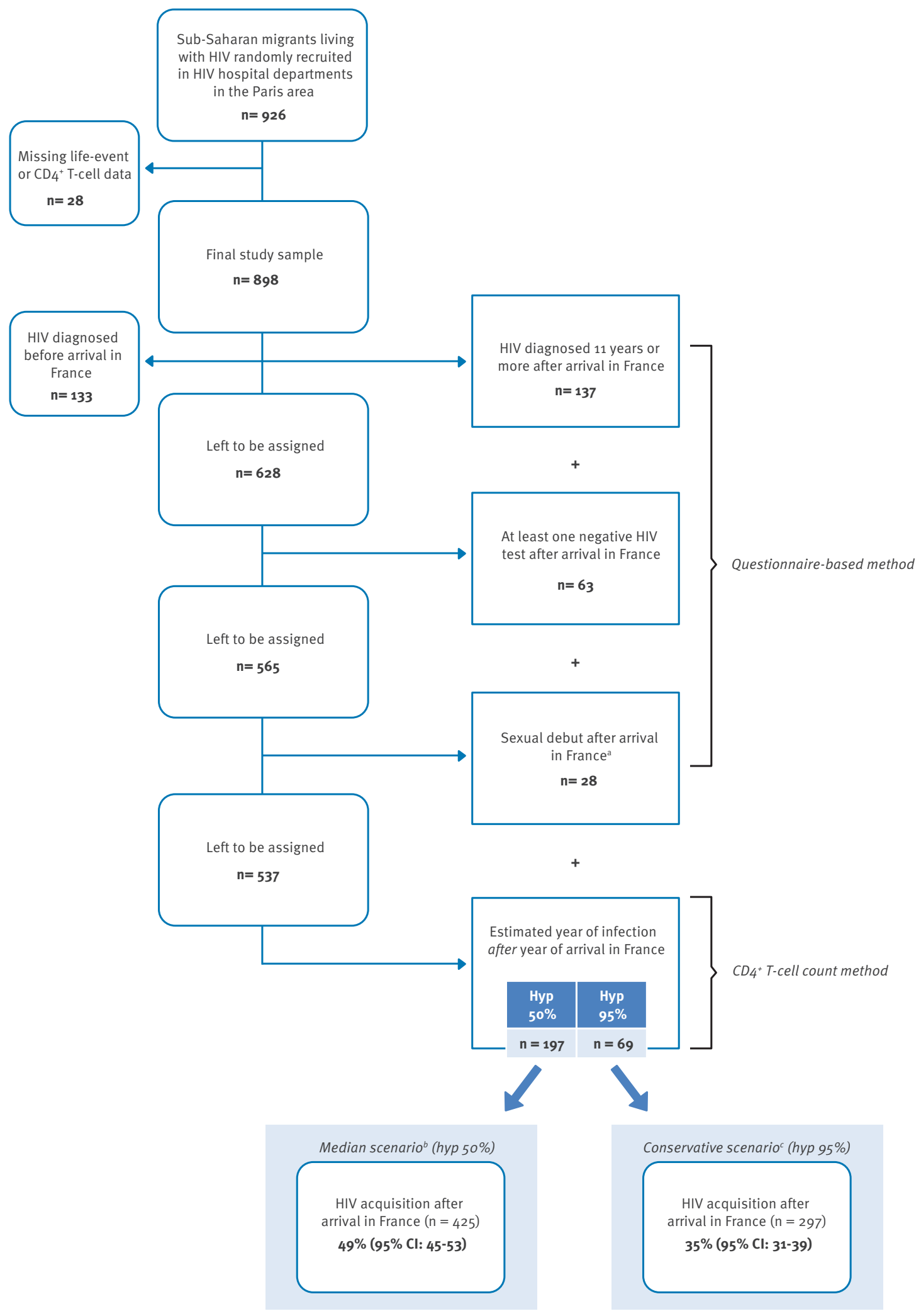

$\mathrm{Cl}$ : confidence interval; HIV: human immunodeficiency virus; hyp: hypothesis.

${ }^{a}$ Infected neither perinatally nor through blood transfusion.

${ }^{b}$ HIV acquisition while living in France if $>50 \%$ of the estimated years of infection fell within the period of staying in France.

' HIV acquisition while living in France if $>95 \%$ of the estimated years of infection fell within the period of staying in France. 
Estimated proportion of sub-Saharan African migrants living with HIV in Paris metropolitan area who acquired HIV after arrival in France, by sociodemographic characteristics and period of diagnosis, February 2012-May 2013 (n=898)

\begin{tabular}{|c|c|c|c|c|c|c|c|c|c|c|}
\hline & \multicolumn{5}{|c|}{ Men } & \multicolumn{5}{|c|}{ Women } \\
\hline & \multirow[b]{2}{*}{$\mathrm{n}$} & \multirow[b]{2}{*}{$\begin{array}{c}\text { Weighted }^{\mathrm{a}} \\
\%\end{array}$} & \multirow[b]{2}{*}{$p$ value } & \multirow{2}{*}{$\begin{array}{l}\text { Univariate } \\
\text { OR }(95 \% \mathrm{Cl})\end{array}$} & \multirow{2}{*}{$\begin{array}{l}\text { Multivariate } \\
\text { OR }(95 \% \mathrm{Cl})\end{array}$} & \multirow[b]{2}{*}{$n$} & \multirow[b]{2}{*}{$\begin{array}{c}\text { Weighted } \\
\%\end{array}$} & \multirow[b]{2}{*}{ p value } & \multirow{2}{*}{$\begin{array}{l}\text { Univariate } \\
\text { OR }(95 \% \mathrm{Cl})\end{array}$} & \multirow{2}{*}{$\begin{array}{l}\text { Multivariate } \\
\text { OR }(95 \% \mathrm{Cl})\end{array}$} \\
\hline & & & & & & & & & & \\
\hline Overall & 348 & 43.9 & & & & 550 & 30.0 & & & \\
\hline \multicolumn{11}{|c|}{ Age at arrival in France } \\
\hline$<25$ years & 84 & 78.1 & \multirow{3}{*}{$<0.001$} & $\begin{array}{c}14.49 \\
(6.84-30.68)\end{array}$ & $\begin{array}{c}2.12 \\
(0.65-6.90)\end{array}$ & 171 & $54 \cdot 1$ & \multirow{3}{*}{$<0.001$} & $\begin{array}{c}11.99 \\
(5.30-27.13)\end{array}$ & $\begin{array}{c}14.99 \\
(4.14-54.25)\end{array}$ \\
\hline $25-34$ years & 139 & $44 \cdot 3$ & & $\begin{array}{c}3.06 \\
(1.47-6.39) \\
\end{array}$ & $\begin{array}{c}0.93 \\
(0.31-2.84) \\
\end{array}$ & 251 & $24 \cdot 5$ & & $\begin{array}{c}3.36 \\
(1.65-6.82) \\
\end{array}$ & $\begin{array}{c}4.55 \\
(1.72-12.03) \\
\end{array}$ \\
\hline$\geq 35$ years & 125 & 19.8 & & Reference & Reference & 128 & 8.4 & & Reference & Reference \\
\hline \multicolumn{11}{|c|}{ Time in France before diagnosis ${ }^{b}$} \\
\hline o to 2 years & 137 & 10.3 & \multirow{4}{*}{$<0.001$} & Reference & Reference & 254 & 5.4 & \multirow{4}{*}{$<0.001$} & Reference & Reference \\
\hline 3 to 5 years & 45 & $19 \cdot 3$ & & $\begin{array}{c}2.25 \\
(0.46-11.04) \\
\end{array}$ & $\begin{array}{c}2.12 \\
(0.44-10.34) \\
\end{array}$ & 93 & 23.4 & & $\begin{array}{c}5.90 \\
(2.95-11.81) \\
\end{array}$ & $\begin{array}{c}6.56 \\
(3.00-14.32) \\
\end{array}$ \\
\hline 6 to 9 years & 39 & $54 \cdot 0$ & & $\begin{array}{c}11.08 \\
(3.44-35.66)\end{array}$ & $\begin{array}{c}14.48 \\
(3.93-53.30) \\
\end{array}$ & 67 & 52.5 & & $\begin{array}{c}21.42 \\
(9.95-46.10)\end{array}$ & $\begin{array}{c}26.44 \\
(12.45-56.15)\end{array}$ \\
\hline $\begin{array}{l}10 \text { years or } \\
\text { more }\end{array}$ & 106 & $93 \cdot 5$ & & $\begin{array}{c}117.38 \\
(25.78-534.49)\end{array}$ & $\begin{array}{l}166.23 \\
(32.25- \\
856.71)\end{array}$ & 95 & 86.0 & & $\begin{array}{c}110.28 \\
(47.48-256.13)\end{array}$ & $\begin{array}{c}219.87 \\
(83.10-581.77)\end{array}$ \\
\hline \multicolumn{11}{|c|}{ Educational level } \\
\hline None/primary & 79 & 40.6 & \multirow{3}{*}{0.51} & Reference & Reference & 104 & 30.7 & \multirow{3}{*}{0.78} & Reference & Reference \\
\hline Secondary & 160 & 41.1 & & $\begin{array}{c}1.02 \\
(0.46-2.27)\end{array}$ & $\begin{array}{c}2.30 \\
(0.88-6.03) \\
\end{array}$ & 334 & 30.8 & & $\begin{array}{c}1.05 \\
\left(0.45^{-2.43)}\right.\end{array}$ & $\begin{array}{c}1.23 \\
(0.65-2.32)\end{array}$ \\
\hline $\begin{array}{l}\text { Higher } \\
\text { education }\end{array}$ & 109 & 50.2 & & $\begin{array}{c}1.45 \\
(0.67-3.11)\end{array}$ & $\begin{array}{c}2.67 \\
(0.74-9.64)\end{array}$ & 112 & 27.1 & & $\begin{array}{c}0.88 \\
(0.28-2.83)\end{array}$ & $\begin{array}{c}1.40 \\
(0.60-3.27)\end{array}$ \\
\hline \multicolumn{11}{|c|}{ Region of birth in sub-Saharan Africa } \\
\hline $\begin{array}{l}\text { Western } \\
\text { Africa }\end{array}$ & 199 & $43 \cdot 5$ & \multirow{3}{*}{0.67} & Reference & Reference & 279 & $35 \cdot 0$ & \multirow{3}{*}{0.16} & Reference & Reference \\
\hline Central Africa & 141 & 43.6 & & $\begin{array}{c}1.00 \\
(0.54-1.85)\end{array}$ & $\begin{array}{c}1.10 \\
(0.48-2.48) \\
\end{array}$ & 259 & 24.8 & & $\begin{array}{c}0.64 \\
(0.38-1.08)\end{array}$ & $\begin{array}{c}0.57 \\
(0.32-1.01)\end{array}$ \\
\hline $\begin{array}{l}\text { Eastern/ } \\
\text { southern } \\
\text { Africa } \\
\end{array}$ & 8 & 62.8 & & $\begin{array}{c}2.26 \\
(0.32-15.98)\end{array}$ & $\begin{array}{c}1.87 \\
(0.05-76.93)\end{array}$ & 12 & 30.2 & & $\begin{array}{c}0.87 \\
(0.18-4.23)\end{array}$ & $\begin{array}{c}0.39 \\
(0.08-1.97)\end{array}$ \\
\hline \multicolumn{11}{|c|}{ Year of diagnosis } \\
\hline $\begin{array}{l}\text { Earlier than } \\
1996\end{array}$ & 49 & 51.7 & \multirow{4}{*}{0.61} & $\begin{array}{c}1.73 \\
(0.84-3.58)\end{array}$ & $\begin{array}{c}1.12 \\
(0.53-2.36)\end{array}$ & 67 & 40.3 & \multirow{4}{*}{0.14} & $\begin{array}{c}1.58 \\
(0.82-3.03) \\
\end{array}$ & $\begin{array}{c}0.27 \\
(0.11-0.69)\end{array}$ \\
\hline $1996-2002$ & 89 & 38.3 & & Reference & Reference & 185 & 29.9 & & Reference & Reference \\
\hline $2003-2007$ & 105 & $45 \cdot 9$ & & $\begin{array}{c}1.40 \\
(0.66-3.01)\end{array}$ & $\begin{array}{c}2.88 \\
(1.01-8.22)\end{array}$ & 179 & 31.7 & & $\begin{array}{c}1.08 \\
(0.61-1.92) \\
\end{array}$ & $\begin{array}{c}2.39 \\
(1.18-4.85)\end{array}$ \\
\hline $2008-2012$ & 105 & 43.0 & & $\begin{array}{c}1.24 \\
(0.51-3.02)\end{array}$ & $\begin{array}{c}2.76 \\
(0.74-10.29) \\
\end{array}$ & 119 & 22.2 & & $\begin{array}{c}0.67 \\
(0.33-1.35)\end{array}$ & $\begin{array}{c}2.50 \\
(1.00-6.24)\end{array}$ \\
\hline
\end{tabular}

$\mathrm{Cl}$ : confidence interval; HIV: human immunodeficiency virus; OR: odds ratio.

a The Table presents the conservative scenario (hypothesis 95\%): HIV acquisition while living in France if $>95 \%$ of the estimated years of infection fell within the period of staying in France. Data were weighted according to each individual's probability of inclusion in the survey (i.e. considering the probability of inclusion in the sample for each healthcare facility, the number of half-days of weekly consultations in each included facility and the individual study participation per half-day of included consultations).

${ }^{b}$ We excluded 21 men and 41 women from this multivariate analysis because data on CD4 $4^{+}$-cell count at diagnosis or before initiation of antiretroviral therapy were unknown.

epidemic in sub-Saharan Africa where women are infected at a younger age and to a higher proportion than men. Since HIV-infected men and women arrive approximately at the same age in France (median: 30 and 28 years, respectively, in our sample), women are more likely than men to be HIV-positive at the time they arrive in Europe. This also indicates that men might be at higher sexual risk in France after migration than women, as already suggested in UK and in France $[19,20]$. That the likelihood of acquiring HIV while living in France increases with time since arrival and with younger age at arrival further supports the validity of our estimation.

In the UK, $31 \%$ of black Africans born outside the UK and diagnosed HIV-positive between 2004 and 2010 
were estimated to have acquired HIV while living in the UK [9]. Consistent figures were previously estimated based on life histories and $\mathrm{CD}_{4}{ }^{+} \mathrm{T}$-cell count at presentation in healthcare centres between 2004 and 2006 [7]. Our results suggest that in France, the proportion of sub-Saharan African migrants living with HIV who acquired their infection after migration is even higher than in the UK. As in the UK, this proportion increased after 2000.

Rice et al. in the UK [9] estimated the time between HIV acquisition and diagnosis based only on modelling of the $\mathrm{CD}_{4}{ }^{+} \mathrm{T}$-cell decline, whereas the major strength of our estimation lies in the combination of life-event and $\mathrm{CD}_{4}^{+} \mathrm{T}$-cell data. Although based on information given by the interviewees, histories of migratory path, HIV testing and sexual debut can be considered reliable since the life-event method greatly supports the recall process and the order of life events as shown previously $[10,21]$. Moreover, this mode of collection decreases the risk of desirability bias because the interviewer can compare the answers given for different periods and fields of the life. If inconsistencies are detected, they can check the reliability of the answer with the patient and correct it. To further strengthen this information, we checked the consistency between dates and circumstances of the negative HIV test in France and other life events such as pregnancies and sexual partnerships (data not shown). We assumed that patients acquired HIV only through sexual intercourse because less than $1 \%$ of sub-Saharan migrants living with HIV in France have been documented as IDU (data not shown, ANRS-VESPA study).

We used $\mathrm{CD}_{4}{ }^{+} \mathrm{T}$-cell modelling to estimate the time between HIV acquisition and diagnosis only when the life-event criterion did not allow us to assign HIV acquisition before or after arrival in France. We modelled the natural decline in $\mathrm{CD}_{4}{ }^{+} \mathrm{T}$-cell counts from a cohort of seroconverters in West Africa [14] to take into account possible genetic specificity of $\mathrm{CD}_{4}{ }^{+} \mathrm{T}$-cell decline in HIV infection [22]. Since HIV disease progression does not differ across individuals from western and central Africa [23], estimates of the decline in $\mathrm{CD}_{4}{ }^{+} \mathrm{T}$-cell count based on data from Côte d'Ivoire are likely to apply to our study population which consisted mostly of people originating from these two regions (96\%). The model was also checked on data with life-event criterion available, and the results were consistent.

Our study has some limitations. Firstly, the natural history of HIV infection may be slightly different between African people living in Europe and those living in Africa: Pantazis et al. have shown that time between HIV infection and a certain level of $\mathrm{CD}_{4}{ }^{+} \mathrm{T}$-cells is shorter in African people diagnosed for HIV in Europe than in African people diagnosed in sub-Saharan Africa [22]. In that case our modelling hypotheses would slightly underestimate the proportion of sub-Saharan African HIV-positive patients having acquired HIV after arrival in France.
Secondly, our estimation does not take into account HIV-positive migrants who are undiagnosed (estimated at ca one in four migrants with HIV [24]) or not in care. In France, migrants have free access to care after three months of residence, regardless of legal status. But it is still possible that some of them, in particular when recently infected and healthy, delayed their entry in care. This suggests that we may have underestimated the proportion of sub-Saharan African migrants living with HIV and having acquired HIV while living in France.

Thirdly, among PARCOURS participants, $1.3 \%$ were infected with HIV-2. Among them, some were assigned, based on life-event data, as having acquired HIV before/ after arrival, leaving only $0.9 \%$ to whom we applied the slope of $\mathrm{CD}_{4}{ }^{+} \mathrm{T}$-cell counts modelled for HIV-1. It is possible that for these $0.9 \%$, we over-estimated the HIV-2 acquisition in France because the decline of $\mathrm{CD}_{4}{ }^{+}$ T-cells is slower in HIV-2 infection. However, considering this low proportion, this is unlikely to have affected our overall results.

Finally, our sample was not large enough to investigate HIV acquisition in France among men who have sex with men (MSM): only $5 \%(n=18)$ of the male participants declared having had male partners in their lifetime. The estimated proportion of post-migration HIV acquisition in this group did not appear significantly different from non-MSM. Nevertheless migrant MSM may be at high risk due to higher stigma and should be targeted in HIV prevention policies.

\section{Conclusion}

Despite possible underestimation, we estimated high levels of HIV acquisition after migration, which undermine the predominant postulate of HIV as a mainly imported epidemic among African migrants in Europe. It seems important that other European countries attempt to quantify post-migration HIV acquisition among migrants [25]. These results are necessary to guide allocation of prevention resources as in most countries in Europe, few prevention resources are allocated to activities targeting migrants because it is assumed that they were infected before arrival. Our results for France emphasise the need for a better understanding of sexual and preventive behaviour after migration to address the unmet preventive needs in the population born in sub-Saharan Africa and to design tailored public health policies in France.

\section{*Erratum}

This sentence was erroneously published as "The decline in CD4+ T-cell count (square root-transformed) over time was estimated using a linear mixed model with random intercept and slope, adjusted for individual $\mathrm{CD}_{4}+\mathrm{T}$-cell count at first CD4+ T-cell count measure (x1) duration from estimated date of HIV seroconversion to first CD4+ T-cell count measure (x1) and age at HIV seroconversion (x1)." The variables were corrected on 20 November 2015 . We apologise for this mistake. 
Further members of the PARCOURS Study Group:

E. Rodary, D. Pourette, J. Situ, P. Revault, P. Sogni, J. Gelly, Y le Strat, N Razafindrasitma.

\section{Acknowledgements}

This study was supported by the French National Agency for research on AIDS and Viral hepatitis (ANRS) and the General Direction of Health (DGS, French Ministry of Health). The sponsor of the study had no role in study design, data collection, data analysis, data interpretation or writing of the paper. The authors would like to thank all those who participated in the study, the RAAC-Sida, COMEDE, FORIM and SOS hepatitis associations for their support in preparing and conducting the survey, G Vivier and E Lelièvre (INED) and Anne Gervais (AP-HP) for their support in preparing the questionnaire, A Guillaume for communication tools, the ClinSearch and Ipsos societies for data collection, and staff at all participating centres:

Hôpital intercommunal de Créteil (I.Delacroix, B.El Harrar, V.Garrait, L.Richier); CHU le Kremlin Bicêtre (M.Duracinski, Y.Quertainmont, C.Goujard, D.Peretti, K.Bourdic); Hôpital Delafontaine (G.Tran Van, M.A.Khuong, M.Poupard, J.Krause, B.Taverne); Hôpital Tenon (P.Bonnard, M.G.Lebrette, H.Cordel, F.X.Lescure, J.P.Vincensini, A.Adda Lievin, P.Thibault, N.Velazquez); CHU Lariboisière (J.F.Bergmann, E.Badsi, J.Cervoni, M.Diemer, A.Durel, P.Sellier, M.Bendenoun, J.D.Magnier); CHU Saint-Antoine (E.Bui, J.Tredup, P.Campa, N.desplanque, M.Sebire); Hôpital Saint-Louis (D.Ponscarme, N.Colin de Verdière, V.de Lastours, J.Gouguel, C.Gatey, C.Lascoux-Combe, V.Garrait, F.Taieb, N.De Castro, L.Gérard); Hôpital Bichat Claude Bernard (G.Pahlavan, B.Phung, F.L'Heriteau, A.Dia, A.Lepretre, G.Morau, C.Rioux, V.Joly, Y.Yazdanpanah, S.Legac); Hôpital René Dubos (L.Blum, M.Deschaud); Hôpital Européen G. Pompidou (M.Buisson, P.Kousignian, C.Minozzi, M.Karmochkine, D.Batisse, J. Pavie, M.Eliaczewicz, L.Weiss, G.Gonzalez, P.Castiel, I.Pierre, M.Beumont, D.Jayle, J.Derouinau, M.Manea, E.Bourzam); Hôpital Avicenne (S.Abgral, S.Mattioni, R Barruet, N.Sayre, O.Bouchaud, M.Tatay, M.Gousseff, F.Mechai, T.Kandel, P.Honoré, M.Coupard); CHU Cochin Tannier (F.Bani-Sadr, L.Belarbi, G.Spiridon, T.Tahi, H.Mehawej, D.Salmon, B.Silbermann, A.Calboreanu, P.Loulergue, H.Bouchez, V.Le Baut, M.P.Pietri); Centre hospitalier de Gonesse (D.Trois Vallets, V.Favret); Hôtel Dieu (J.P.Viard, A.Sobel, J.Gilquin, A.Cros, A.Maignan); CHI Poissy/Saint-Germain-en-Laye (Y.Welker, H.Masson, B.Montoya, J.L.Ecobichon); CH de Lagny Marne la Vallée (E.Froguel, P.Simon, M.S.Nguessan, S.Tassi); Nouveau Centre Hospitalier Sud Francilien (A.Devidas, L.Gerard, H.Touahri); CHI Robert Ballanger (J.L.Delassus, M.A.Bouldouyre, V.Favret); Hôpital Intercommunal André Grégoire (C.Winter); Hôpital La pitié Salpetrière (S.Pelletier, M.C.Samba, S.Herson, A.Simon, M.Bonmarchand, N.Amirat, N.Smail, S.Seang, H.Stitou, L.Schneider, R.Tubiana, L.Epelboin, M.A.Valantin, C.Katlama, S.Ben Abdallah, P.Bourse, Y.Dudoit, C.Blanc); Centre Médical Institut Pasteur (C.Charlier-Woerther, O.Lortholary, P.H.Consigny, A.Gergely, M.Shoai-Tehrani, G.Cessot, C.Duvivier, F.Touam, K.Benhadj); CMC de Bligny (H.Ait Mohand, E.Klement, P.Chardon).

We thank the ANRS 1220 PRIMOCI group (PI Albert Minga and Xavier Anglaret) who accepted to share with us the data on natural decline in CD4+ T-cells among the PRIMO CI Ivoirian cohort of seroconverters.

\section{Conflict of interest}

None declared.
Authors' contributions

ADL, RDS, FL, NB and NL designed the research and organised the data collection, JP, AR and AG prepared the data, VS conceived and designed the $\mathrm{CD}_{4}$-count based modelling approach, JP, AR, AG and ADL analysed the data, ADL and JP drafted the manuscript and ADL, RDS, FL, VS, HP, NB, NL critically revised the manuscript for important intellectual content.

\section{References}

1. Hamers FF, Downs AM. The changing face of the HIV epidemic in western Europe: what are the implications for public health policies? Lancet. 2004;364(9428):83-94. DOI: 10.1016/S01406736(04)16594-X PMID: 15234861

2. Del Amo J, Likatavičius G, Pérez-Cachafeiro S, Hernando V, González C, Jarrín I, et al. The epidemiology of HIV and AIDS reports in migrants in the 27 European Union countries, Norway and Iceland: 1999-2006. Eur J Public Health. 2011;21(5):620-6. DOI: 10.1093/eurpub/ckq150 PMID: 21051469

3. Cazein F, Lot F, Pillonel J, Le Strat Y, Sommen C, Pinget R, et al. (Discoveries of HIV seropositivity and AIDS: France, 20032012). Découvertes de séropositivité VIH et de sida: France, 2003-2012.Bull Epidémiologique Hebd.2014;9-10:154-62.

4. ANRS-Vespaz study group,Tron L, Lert F, Spire B, Dray-Spira R. Tobacco smoking in HIV-infected versus general population in france: heterogeneity across the various groups of people living with HIV.PLoS ONE. 2014;9(9):e107451. DOI: 10.1371/ journal.pone.0107451 PMID: 25202968

5. Institut national de la statistique et des études économiques (INSEE). Immigrés et descendants d'immigrés en France, édition 2012 [Immigrants and descendants of immigrants in France, edition 2012]. Paris: INSEE; 2012. French. Available from: http://www.insee.fr/fr/ffc/docs_ffc/ref/IMMFRA12_g_ Flot1_pop.pdf

6. Le Vu S, Le Strat Y, Barin F, Pillonel J, Cazein F, Bousquet V, et al. Population-based HIV-1 incidence in France, 2003-08: a modelling analysis. Lancet Infect Dis. 2010;10(10):682-7. DOI: 10.1016/S1473-3099(10)70167-5 PMID: 20832367

7. SONHIA collaboration group,Burns FM, Arthur G, Johnson AM, Nazroo J, Fenton KA. United Kingdom acquisition of HIV infection in African residents in London: more than previously thought.AIDS. 2009;23(2):262-6. DOI: 10.1097/ QAD.ob013e32831C546b PMID: 19098498

8. European Centre for Disease Prevention and Control (ECDC). ECDC and Spanish Ministry of Health workshop: Improving the monitoring of HIV among migrant populations in Europe. Madrid: 3-4 October 2013; 2013. Available from: http://ec.europa.eu/health/sti_prevention/docs/ ev_20131210_c008_en.pdf

9. Rice BD, Elford J, Yin Z, Delpech VC. A new method to assign country of HIV infection among heterosexuals born abroad and diagnosed with HIV.AIDS. 2012;26(15):1961-6. DOI: 10.1097/ QAD.ob013e3283578b80 PMID: 22781226

10. Le Cœur S, Im-em W, Koetsawang S, Lelièvre É. Vulnérabilité et vie avec le VIH en Thaïlande : l'apport de l'approche biographique. [Living with HIV in Thailand: assessing vulnerability through a life-event history approach].Population (Paris). 2005;60(4):551-68. French.DOI: 10.3917/pope.504.0473

11. Ndawinz JDA, Costagliola D, Supervie V. New method for estimating HIV incidence and time from infection to diagnosis using HIV surveillance data: results for France.AIDS. 2011;25(15):1905-13. DOI: 10.1097/QAD.obo13e32834af619 PMID: 21811147

12. Supervie V, Ndawinz JDA, Lodi S, Costagliola D. The undiagnosed HIV epidemic in France and its implications for HIV screening strategies.AIDS. 2014;28(12):1797-804. DOI: 10.1097/QAD.0000000000000270 PMID: 24681416

13. Ndawinz JDA, Anglaret X, Delaporte E, Koulla-Shiro S, Gabillard $D$, Minga A, et al. New indicators for delay in initiation of antiretroviral treatment: estimates for Cameroon. Bull World Health Organ. 2015;93(8):521-8. DOI: 10.2471/BLT.14.147892 PMID: 26478609

14. Minga AK, Lewden C, Gabillard D, Bomisso GI, Toni TD, Emième $A A$, et al. CD4 cell eligibility thresholds: an analysis of the time to antiretroviral treatment in HIV-1 seroconverters. AIDS. 2011;25(6):819-23. DOI: 10.1097/QAD.obo13e32834625d3 PMID: 21412060

15. Thomas D, Luk W. Sampling from the multivariate Gaussian distribution using reconfigurable hardware. In: Fieldprogrammable custom computing machines, 2007. FCCM 2007. 15th Annual IEEE Symposium, 23-25 April 2007. Available 
from: http://cas.ee.ic.ac.uk/people/dt10/research/thomas-07multivariate-gaussian.pdf

16. Lert F, Annequin M, Tron L, Aubrière C, Hamelin C, Spire B, et al. Situation sociale et état de santé des personnes vivant avec le VIH aux Antilles, en Guyane et à La Réunion en 2011. Premiers résultats de l'enquête ANRS-Vespaz. [Social situation and health status of people living with HIV in the Antilles, Guyana and Reunion in 2011. First results of the ANRS-Vespa2 investigation]. Bull Epidémiologique Hebd.2013;26-27:293-9. French.

17. Ministère des affaires sociales et de la santé, Morlat $P$. Prise en charge médicale des personnes vivant avec le VIH. Recommandations du groupe d'experts. Rapport 2013 [Medical care for people living with HIV. Recommendations of the expert group. 2013 report]. Paris: Direction de l'information légale et administrative; 2013. French. Available from: http://www. sante.gouv.fr/IMG/pdf/Rapport_Morlat_2013_Mise_en_ligne. pdf

18. Lucas E, Cazein F, Brunet S, Thierry D, Pillonel J, Lot F, et al. Types, groupes et sous-types de VIH diagnostiqués en France depuis 2003: données de huit années de surveillance. [Types, groups and subtypes of HIV diagnosed in France since 2003: data from eight years of surveilance]. Bull Épidémiologique Hebd. 2012;(46-47):533-7. French.

19. Fenton KA, Mercer CH, McManus S, Erens B, Wellings K, Macdowall W, et al. Ethnic variations in sexual behaviour in Great Britain and risk of sexually transmitted infections: a probability survey. Lancet. 2005;365(9466):1246-55. DOI: 10.1016/S0140-6736(05)74813-3 PMID: 15811458

20. Marsicano E, Lydié N, Bajos N. 'Migrants from over there' or 'racial minority here'? Sexual networks and prevention practices among sub-Saharan African migrants in France.Cult Health Sex. 2013;15(7):819-35. DOI: 10.1080/13691058.2013.785024 PMID: 23659520

21. Pailhé A, Robette N, Solaz A. Work and family over the life-course. A typology of French long-lasting couples using optimal matching.Longit Life Course Stud. 2013;4(3):196-217.

22. Pantazis N, Morrison C, Amornkul PN, Lewden C, Salata RA, Minga $A$, et al. Differences in HIV Natural History among African and Non-African Seroconverters in Europe and Seroconverters in Sub-Saharan Africa. Wilkinson RJ, editor. PLoS ONE. 2012;7(3):e32369.

23. Laurent C, Bourgeois A, Faye MA, Mougnutou R, Seydi $M$, Gueye $M$, et al. No difference in clinical progression between patients infected with the predominant human immunodeficiency virus type 1 circulating recombinant form (CRF) 02_AG strain and patients not infected with CRFo2_AG, in Western and West-Central Africa: a four-year prospective multicenter study. J Infect Dis. 2002;186(4):486-92. DOI: 10.1086/341833 PMID: 12195375

24. Supervie V, Costagliola $D$. The spectrum of engagement in HIV care in France : strengths and gaps. 2oth Conference on Retroviruses and Opportunistic Infections. Atlanta, March 2013. Abstract \#:1030. 2013.

25. Fakoya I, Álvarez-del Arco D, Woode-Owusu M, Monge S, Rivero-Montesdeoca Y, Delpech V, et al. A systematic review of post-migration acquisition of HIV among migrants from countries with generalised HIV epidemics living in Europe: mplications for effectively managing HIV prevention programmes and policy. BMC Public Health. 2015;15(1):561. DOI: $10.1186 /$ s12889-015-1852-9 PMID: 26085030 